\title{
Usage of EduBlogs Among Malaysian Secondary School Students
}

\author{
Arumugam Raman \\ University utara Malaysia \\ arumugam@uum.edu.my \\ Yahya Don \\ University utara Malaysia \\ d,yahya@uum.edu.my \\ Yaakob Daud \\ University utara Malaysia \\ yaakob@uum.edu.my
}

Doi:10.5901/mjss.2015.v6n5p500

\begin{abstract}
Most of the western countries integrated Edublogs in their instruction process (Morris, 2015). However the Malaysian education setting blogs usage is still in early stages. The main purpose of this study is to investigate the technology acceptance level through UTAUT model. The research was conducted on 53 Form 4 secondary schools students from Kual Muda District. All the students studying science subject and exposed to Edublogs during instruction. A set of questionnaire which is adapted from Venkatesh et al. (2003) was used to collect data and then analyzed using SPSS and SmartPLS software. The results revealed that Performance Expectancy, Social Influence and Facilitating Conditions have significant positive effect on Behavioral Intention. The $R 2$ value 0.412 reflects that $41.2 \%$ of the variance in Behavioral Intention can be explained by Performance Expectancy, Social Influence, Facilitating Conditions and Effort Expectancy. It is expected that this study will help teachers and students integrate Edublog technology in teaching and learning process.
\end{abstract}

Keywords: EduBlogs, "Unified theory of acceptance and use of technology (UTAUT), Performance Expectancy (PE), Effort Expectancy (EE), Social Influence (SI), Facilitating Conditions (FC)".

\section{Introduction}

Edublogs are interactive web based software that enables students to present themselves in a social environment (Anderson, 2005). Further Anderson (2005) found that social presence "is correlated with the student satisfaction and higher scores on learning outcomes" and (Garrison, Anderson \& Archer, 2000) defined as "the ability to present oneself" to other users. Xie and Sharma (2005) concluded blogging operates as a means to track their personal activity and experiences to revise for reflection purposes. Edublogs are accustomed to most developed countries, however in Malaysian context it is still new. Google search confirms that there are limited researches in this area. Therefore, this study is providing an additional literature on blogging in Malaysia schools. The objective of this study to investigate the blogging technology acceptance level of Malaysian students based on UTAUT model. The previous study which was conducted by Song and Chan (2008) regarding the acceptance level of blogs as learning tools suggested that there are some challenges blocking that usage of the blogs in Malaysian context. Further the study also revealed that Malaysian students are ready to use blogs in their learning process. This study goes on step further, tried to exploit the Edublogs technology acceptance among form four Malaysian students. 


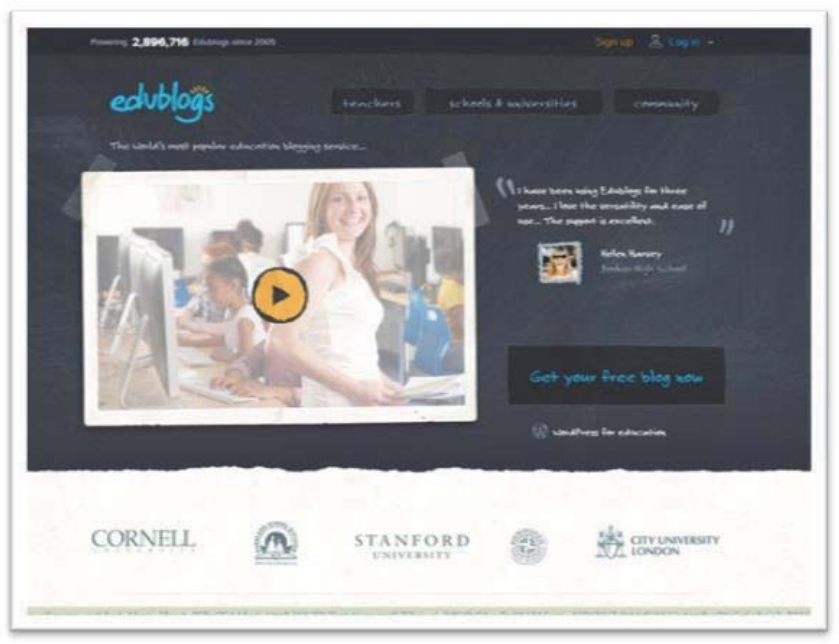

Figure 1: Edublogs.org

\section{Literature Review}

Various researches revealed that Edublogs engaged meaningful communication and collaboration between two parties.. William and Jacobs (2004) investigated the advantages of using blogs. They concluded that blogs enable 'high level autonomy and provides greater opportunity for contact among students". On the other hand they identified that the highly positive use of blogs in learning process will increase the collaborative and reflective among them. Another study conducted by Ferdig \& Trammel (2004) intensely proposed that blogs are more effective in terms of interactivity and conversational than asynchronous forums. Further the researchers added that the teacher-student association becomes more meaningful in conversational environment. Besides this there are many studies have reported the use of blogs in various academic levels (Betts \& Glogoff, 2004; Glogoff, 2005; Du \& Wagner, 2006; Chong \& Soo, 2007; Ramaswami, 2008;). Ramaswami (2008) studied about using blogs in improving students writing and writing better. Another noteworthy study by Ocker \& Yaverbaum, 2001, cited in Kim, (2008) revealed that "blogging sharpened critical and problem solving skills".

The main aim "this study is to measure the acceptance level of Edublogs among form 4 Malaysian students. In order to measure the acceptance level the researchers adapted Unified theory of acceptance and use of technology (UTAUT) model. This model is developed by Venkatesh, Morris, Davis, and Davis et al (2003). It is combination of eight technology acceptance models, namely (i) Theory of Reasoned Action (TRA), (ii) technology Acceptance Model (TAM), (iii) Motivational Model, (iv) Theory Planned Behavior, (v) Combined TAM-TPB, (vi) Model of PC Utilization, (vii) Innovation Diffusion Theory, (viii) Social Cognitive Theory. The final UTAUT model postulates that four key constructs, that is, performance expectancy, effort expectancy, social influence, and facilitating conditions are direct determinants of usage behavior (Raman et al., 2014)". The "performance expectancy (PE) means the degree to which an individual believes that using the system will help him or her to attain gains in studies; Effort expectancy (EE) is the degree of ease associated with the use of the system; Social influence (SI) means the degree to which an individual perceives that others believe he or she should use the new system; Facilitating conditions (FC) is the degree to which an individual believes that an organizational and technical infrastructure exists to support use of the system (Raman et al, 2014)."

UTAUT model mostly used in business environments such as measure the adaptation of new technology in recognizing the factors of acceptance by the aimed groups of users. This study is focusing on students Edublogs acceptance in secondary schools context. There are very few studies accessing student's blogging acceptance by secondary school students. "Pardamean and Susanto (2012) used UTAUT model to investigate students' acceptance of blog technology to learn e-business. They found that SI and PE have a "significant relationship with behavioral intention (BI)". By contrast EE is not significant towards BI. This proves that PE and SI play an important role in blog technology acceptance. Wong, Teo and Russco (2013) examined the Interactive Smartboard Acceptance via UTAUT model. They used structural equation modeling (SEM) the model verified by the data. It was found that "the model explained $59.6 \%$ of 
the variance of the students teachers intention to use the Smartboard technology". Another study by El-Gayar, Moran and Hawkes (2011) used UTAUT model to measure "Students Acceptance of Tablet PCs and Implications for Educational Technology And Society explained that the main driver Tablet Technology Acceptance is students themselves (attitude) then followed by PE, FC, EE and SI".

\subsection{Hypotheses}

Research Hypotheses:

$\mathrm{H}_{1}$ : Performance expectancy (PE) is significantly correlated with Behavioral Intention (BI).

$\mathrm{H}_{2}$ : Effort expectancy (EE) is significantly correlated with Behavioral Intention (BI).

$\mathrm{H}_{3}$ : Social influence (SI) is significantly correlated with Behavioral Intention (BI).

$\mathrm{Ho}$ : A facilitative condition ( $\mathrm{FC}$ ) is significantly correlated with Behavioral Intention (BI).

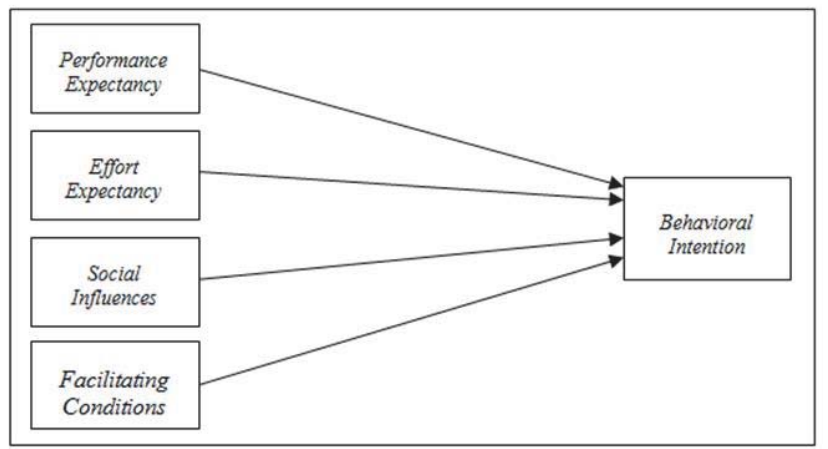

Figure 1: Proposed Framework

\section{Methodology}

The population is Malaysian Form 4 secondary school students. The researchers used convenience sampling to choose 53 Form 4 students in Kubang Pasu District from state of Kedah, Malaysia. The 53 students involved in Edublog integrated instruction. The teacher instructed all students use Edublogs to extract information about cell structure (Biology). Students created posts create pages, comments and participate in forums for two weeks continually. At the end of the two weeks researchers distributed questionnaire (30 questions) to each student which consists of Likert Scale (1) Strongly Disagree to (5) Strongly Agree. All the data analyzed using statistical packages such as SPSS and SmartPLS 3.2.0.

\section{Findings}

The table below shows (Table 1) shows the sample distribution where 25 of them are male; whereas 28 are female. It is obvious that female shared bigger percentage than male. Therefore the researchers not use gender as moderator in this research as suggested by previous studies.

Table 1: Respondents by gender

\begin{tabular}{ccc}
\hline Gender & Frequency & Percentage (\%) \\
\hline Male & 25 & 47.17 \\
Female & 28 & 52.83 \\
Total & 53 & 100 \\
\hline
\end{tabular}

Even though PLS-SEM gives priority to individual reliability researchers found that it is important to report Cronbach alpha. Hair et al. (2010) stated that, "the level of reliability of an instrument is shown when the responses are consistent". 
Table 2 shows the reliability of each latent variables. "UTAUT Model is reflective in nature and Hair et al. (2011) posit that composite reliability (CR) must exceed 0.7 , reliability of items (loadings) must exceed 0.70 , convergent validity (AVE) must exceed 0.50 and the square root of discriminant validity AVE for each construct must be higher compared to the correlation with other constructs (Fornell- Larcker, 1981)".

As shown in the table all the values are above 0.6 as supported by Nunnally and Berstein (1994).

Table 2: Reliability

\begin{tabular}{lc}
\hline Construct & Cronbach Alpha a \\
\hline Performance Expectancy (PE) & 0.76 \\
Effort Expectancy (EE) & 0.68 \\
Social Influence (SI) & 0.79 \\
Facilitating Conditions (FC) & 0.71 \\
Behavioural Intention (BI) & 0.84 \\
\hline
\end{tabular}

\subsection{Convergent Validity}

In order to measure convergent validity, researchers used the outer loadings of the indicators, to Average Variance Extracted (AVE). According to Hair et al (2011) "the AVE value of 0.5 or higher indicates that, on average, more remains in the items than the variance explained that each item completes a part of the item variant. However, an AVE less than 0.5 indicate that, on average, more error remains in the items than the variants explained by the construct".

Table 3: Convergent Validity

\begin{tabular}{|c|c|c|c|c|}
\hline Construct & & Loadings & AVE & $\overline{C R}$ \\
\hline \multirow[t]{6}{*}{ Performance Expectancy PE) } & PE1 & 0.8650 & 0.6187 & 0.9059 \\
\hline & PE2 & 0.7520 & & \\
\hline & PE3 & 0.8120 & & \\
\hline & PE4 & 0.8910 & & \\
\hline & PE5 & 0.6410 & & \\
\hline & PE6 & 0.7310 & & \\
\hline \multirow[t]{6}{*}{ Effort Expectancy (EE) } & EE1 & 0.7810 & 0.6699 & 0.9239 \\
\hline & EE2 & 0.8310 & & \\
\hline & EE3 & 0.7410 & & \\
\hline & EE4 & 0.8610 & & \\
\hline & EE5 & 0.8600 & & \\
\hline & EE6 & 0.8300 & & \\
\hline \multirow[t]{4}{*}{ Social Influence (SI) } & SI1 & 0.8621 & 0.7393 & 0.9189 \\
\hline & $\mathrm{SI} 2$ & 0.9110 & & \\
\hline & $\mathrm{SI} 3$ & 0.8541 & & \\
\hline & $\mathrm{SI} 4$ & 0.8091 & & \\
\hline \multirow[t]{6}{*}{ Facilitating Conditions (FC) } & FC1 & 0.8010 & 0.6886 & 0.9297 \\
\hline & FC2 & 0.8510 & & \\
\hline & FC4 & 0.7610 & & \\
\hline & FC5 & 0.8740 & & \\
\hline & FC6 & 0.8980 & & \\
\hline & FC7 & 0.7850 & & \\
\hline \multirow[t]{4}{*}{ Behavioural Intention (BI) } & $\mathrm{Bl} 1$ & 0.8450 & 0.6628 & 0.8862 \\
\hline & $\mathrm{B} 12$ & 0.9240 & & \\
\hline & $\mathrm{BI} 3$ & 0.7070 & & \\
\hline & $\mathrm{BI} 4$ & 0.7640 & & \\
\hline
\end{tabular}

The above table (Table 3) clearly revealed that the outer loadings are more than 0.7 except items PE5 and FC4. However both items are retained because it does not increase the AVE if dropped. However, item FC3 is omitted because the loading is very low (0.027). The table also shows the values for AVE more than 0.5 . Therefore Convergent Validity establish for this research. 
Table 4: Correlation Matrix

\begin{tabular}{lccccc}
\hline & $\begin{array}{c}\text { Performance } \\
\text { Expectancy (PE) }\end{array}$ & $\begin{array}{c}\text { Effort Expectancy } \\
(\mathrm{EE})\end{array}$ & $\begin{array}{c}\text { Social } \\
\text { Influence (SI) }\end{array}$ & $\begin{array}{c}\text { Facilitating } \\
\text { Conditions (FC) }\end{array}$ & $\begin{array}{c}\text { Behavioural } \\
\text { Intention (BI) }\end{array}$ \\
\hline Performance Expectancy (PE) & $\mathbf{0 . 7 8 6 6}$ & & & & \\
Effort Expectancy (EE) & 0.6012 & $\mathbf{0 . 8 1 8 5}$ & & & \\
Social Influence (SI) & 0.5112 & 0.6036 & $\mathbf{0 . 8 5 9 8}$ & & \\
Facilitating Conditions (FC) & 0.2132 & 0.5136 & 0.3270 & 0.8298 & \\
Behavioural Intention (BI) & 0.3258 & 0.2168 & 0.2141 & 0.3261 & $\mathbf{0 . 8 1 4 1}$ \\
\hline
\end{tabular}

\subsection{Discriminant Validity}

Fornell dan Larcker (1981) stated if the square root of AVE surpassed the latent variables correlations then it is considered discriminant validity exist. The each bold number in table 4 is higher that the corresponding correlations.

Next the researchers calculated the $t$ and $p$ values by conducting bootstrapping using SmartPLS software. The path coefficients $(\beta)$ have standardized values between -1 and +1 . The table shows that $P E>B I=(\beta=0.4210, p<0.05)$; $S I>B I=(\beta=0.2450, p<0.05)$ and $F C>B I=(\beta=0.1350, p<0.05)$, have significant relationship towards Behavioral Intention $(\mathrm{BI})$. However $\mathrm{EE}>\mathrm{BI}=(\beta=0.0470, p>0.05)$; therefore we can conclude there is no significance relationship between $\mathrm{EE}$ and $\mathrm{BI}$. Finally three hypotheses are accepted $\left(\mathrm{Ho}_{1}, \mathrm{HO}_{3}\right.$ and $\left.\mathrm{HO}_{4}\right)$; but $\mathrm{Ho}_{2}$, rejected. $\mathrm{R}^{2}$ value is 0.412 tells that $41.2 \%$ variance explained by predictor variables and it is considered as moderate (Hair, Ringle, \& Sarstedt, 2011; Henseler et al., 2009).

Table 5: Path Coefficients in structural model

\begin{tabular}{cccccc}
\hline Hypotheses & Relationship & Coefficient $(\boldsymbol{\beta})$ & $t$ value & $p$ value & Result \\
\hline $\mathrm{HO}_{1}$ & $\mathrm{PE} \rightarrow \mathrm{BI}$ & 0.4210 & 2.6120 & 0.0117 & Accepted \\
$\mathrm{HO}_{2}$ & $\mathrm{EE} \rightarrow \mathrm{BI}$ & 0.0470 & 0.2111 & 0.8336 & Rejected \\
$\mathrm{HO}_{3}$ & $\mathrm{SI} \rightarrow \mathrm{BI}$ & 0.2450 & 3.1240 & 0.0029 & Accepted \\
$\mathrm{HO}_{4}$ & $\mathrm{FC} \rightarrow \mathrm{BI}$ & 0.1350 & 2.566 & 0.0132 & Accepted \\
\hline
\end{tabular}

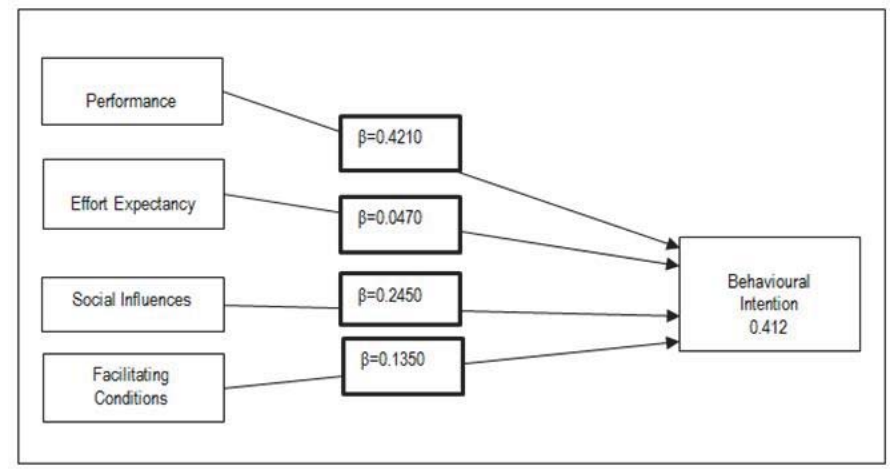

Figure 2: Result of structural model

\section{Discussion and Conclussion}

This study aimed to identify the structural relationship between modified UTAUT constructs. It was found that the three variables except the EE show significant positive relationship towards BI. This study supports "Pardamean \& Susanto (2012) who found that the media interactive function of e-learning can attract the interest and attention of the students. They also agreed that e-learning media is suitable for collaboration and sharing of knowledge. This clearly shows that social and environment factors or SI is the booster for students to use blog in their e-commerce learning. To hasten the implementation of blog in e-commerce learning, encouragement and support from peers is vital. The findings in this study 
are similar with El-Gayar et al. (2011) where they found that the main determiner of Tablet PCs acceptance among students is the students' attitude followed by PE, FC, EE and SI but the result of this study is dissimilar in terms of gender influence in The UTAUT Model which can be seen in the study by Alfonso et al. (2012). Their study aimed at testing the gender effect with a sample of 2,175 users of Electronic Document Management System (EDMS) at the Portuguese City Council. The result showed that gender when related to PE with BI proved to have a strong relationship among male than female. However, further research needs to be done with regards to time allotted for the students and also computer skills among the students to get a better picture of the acceptance of Edublogs among other students in Malaysia. Our study was conducted with secondary school students, compared to many other studies which are conducted with graduate students (Betts \& Glogoff, 2004; Efimova \& de Moor, 2005; Freeman et al., 2006; Hernandez-Ramos, 2004; Xie \& Sharma, 2005). Self-disclosure and the establishment of a social presence was one of the primary uses of blogging for the eight students. Other studies have also found that self-disclosure is one of the most common forms of online communication (Joinson, 2001; Joinson \& Paine, in press). Students showed that they are naturally inclined to disclose personal information, and found that this aspect of social presence encouraged greater involvement in the online community". More researches must be conducted about Edublogs in order to find precise answer towards integration in Malaysian education setting. This will help stakeholders realise the importance of this technology.

\section{Reference}

Afonso, C. M., Roldán, J. L., Sánchez-Franco, M., \& Gonzalez, M. de la O. (2012). The moderator role of Gender in the Unified Theory of Acceptance and Use of Technology (UTAUT): A study on users of Electronic Document Management Systems. Presented at the 7th International Conference on Partial Least Squares and Related Methods, Houston, Texas, USA.

Anderson, T. (2005). Distance learning - Social software's killer ap? Paper presented at the Open and Distance Learning Association of Australia, Breaking the boundaries: The international experience in open, distance and flexible education.http://www.unisa.edu. au/odlaaconference/PPDF2s/13\%20odlaa\%20-\%20Anderson.pdf

Raman, A., Don, Y., Khalid, R., \& Rizuan, M. (2014). Usage of Learning Management System (Moodle) among Postgraduate Students: UTAUT Model. Asian Social Science, 10(14), p186.

Raman, A., Don, Y., Khalid, R., Hussin, F., Omar, M. S., \& Ghani, M. (2014). Technology Acceptance on Smart Board among Teachers in Terengganu Using UTAUT Model. Asian Social Science, 10(11), p84.

Betts, J. D., \& Glogoff, S. J. (2004). Instructional models for using weblogs in elearning: a case study from a virtual and hybrid course. Paper presented at the syllabus 2004

conference, San Francisco, CA, July. Retrieved 05.01.09, Available from: http://download.101com.com/syllabus/conf/summer2004/ PDFs/w01.pdf.

Chong, E. K. M., \& Soo, W. M. (2007). Adaptive learning through blogging: a case study in music teaching. In C. Shegar, \& R. A. Rahim (Eds.), Redesigning pedagogy: Voices of practitioners (pp. 15e31). Singapore: Pearson.

Du, H. S., \& Wagner, C. (2006). Weblog success: exploring the role of technology. International Journal of Human-Computer Studies, $64,789 \mathrm{e} 798$.

Efimova, L., \& de Moor, A. (2005). Beyond personal webpublishing: An exploratory study of conversational blogging practices. Paper presented at the 2005 Proceedings of the 38th Hawaii International Conference on System Sciences.http://csdl2.computer.org/ comp/proceedings/hicss/2005/2268/04/22680107a.pdf

El-Gayar, O.F., Moran, M., \& Hawkes, M. (2011). Student's acceptance of tables PCs and implications for educational instructions. Educational Technology \& Society. 14(2). 58-70.

Freeman, W., \& Brett, C. Dixon, J., Kostuch, L., MacKinnon, K., McPherson, G., Paradine, A., Qiu, M., \& Symington, D. (2006). Weblogging as a part of academic practice: Reflections on graduate students' early experiences. Paper presented at the 2006 International Association for Development of the Information Society Virtual Multi Conference on Computer Science and Information Systems.http://www.iadis.org/Multi2006/Papers/17/S026_EL.pdf

Ferdig, R. E., \& Trammell, K. D. (2004). Content delivery in the 'blogosphere'. TH E Journal, 31(7), 12-20

Fornell C. \& Larcker D.F. (1981). Evaluating structural equation models with unobservable variables and measurement error. Journal of Marketing Research 48: 39-50.

Garrison, R., Anderson, T., \& Archer, W. (2000). Critical inquiry in text-based environment: Computer conferencing in higher education. The Internet and Higher Education, 2(2-3), 87-105.http://communitiesofinquiry.com/documents/Critical_Inquiry_ model.pdf

Glogoff, S. (2005). Instructional blogging: promoting interactivity, student-centered learning, and peer input. Available from: Innovate, 1 http://www.innovateonline.info/index.php?view1/4article\&id1/4126, retrieved 04.12.08.

Hair J.F., Black W.C., Babin B.J. \& Anderson R.E. (2010). Multivariate Data Analysis. 7th Ed. Upper Saddle River, New Jersey: Prentice Hall.

Hair, J. F., Ringle, C. M., \& Sarstedt, M. (2011). PLS-SEM: Indeed a silver bullet. The Journal of Marketing Theory and Practice, 19(2), 139-152.

Hedgebeth, D. (2007). Gaining competitive advantage in a knowledge-based 
economy through the utilization of open source software', The journal of information and knowledge management systems, 37 (3), 284294.

Hernandez-Ramos, P. (2004). Web logs and online discussions as tools to promote reflective practice. The Journal of Interactive Online Learning, 3(1).http://www.ncolr.org/jiol/issues/PDF/3.1.4.pdf

Kim, H. N. (2008). The phenomenon of blogs and theoretical model of blog use in educational contexts. Computers \& Education, 51, $1342 \mathrm{e} 1352$.

Morris, K. (2015, Mac 2). Blogging and the literacy curriculum [Web log post]. Retrieved from http://primarytech.global2.vic.edu.au/ author/2kmand2kjl

Ocker, R. J., \& Yaverbaum, G. J. (2001). Collaborative learning environments: Exploring student attitudes and satisfaction in face-to-face and asynchronous computer conferencing settings. Journal of Interactive Learning Research, 12, 427e449.

Oye, N.D., lahad, N.A., \& Zairah Ab. Rabin. (2011). A model of ICT acceptance and use for teachers in higher education institutions. International Journal of Computer Science \& Communication Networks. 1(1). 21-40.

Pardamean, B., \& Susanto, M. (2012). Assessing user acceptance toward blog technology using the UTAUT model. International Journal of Mathematics and Computers in Simulation. 1(6). 203-212.

Ramaswami, R. (2008). The prose of blogging (and a few cons, too). T.H.E. Journal, Available from: http://www.thejournal.com/articles/ 23562_3, retrieved 18.12.08.

Song, H.S.Y \& Yuen, M.C. (2008). Educational blogging: A Malaysian university students' perception and experience. In Hello! Where are you in the landscape of educationaltechnology? Proceedings ascilite Melbourne 2008.

http://www.ascilite.org.au/conferences/melbourne07/procs/song.pdf

Venkatesh, V. \& Zhang, X. (2010). Unified theory of acceptance and use of technology: U.S. vs. China. Journal of Global Information Technology Management,. 13, (1). 5-27.

Venkatesh, V., Morris, M., Davis, G., Davis, F., DeLone, W., McLean, E., Jarvis, C.,

MacKenzie, S., Podsakoff, P., \& Chin, W. (2003): User acceptance of information technology: Toward a unified view. Inform Management 27, 425-478

Venkatesh, V., Morris, M.G., Davis, G. B., \& Davis, F. D. (2003). User acceptance of information technology: Toward a unified view. MIS Quarterly, 27(3), 425-478

Williams, J. B., \& Jacobs, J. (2004). Exploring the use of blogs as learning spaces in the higher education sector. Australasian Journal of Educational Technology, 20(2), 232e237

Wong, K.T., Teo, T., \& Russo, S. (2013). Interactive whiteboard acceptance :Applicability of the UTAUT model to student teachers. Asia Pacific Edu Res. 22(1). 1-10. DOI 10.1007/s40299-012-0001-9.

Xie, Y., \& Sharma, P. (2005). Students' lived experience of using weblogs in a class: An exploratory study. http://ernie.concordia.ca/ra_ levin/weblogs_and_higher_education.pdf 